\title{
A potência das imagens e da fabulação criadora para o pesquisar no cotidiano escolar
}

\author{
The potency of images and creative fabulation for research in everyday school \\ life
}

\section{La potencia de las imágenes y de la fabulación creadora para la investigación en el cotidiano escolar}

\author{
Janete Magalhães Carvalho ${ }^{2}$ \\ Steferson Zanoni Roseiro
}

\begin{abstract}
Resumo: Objetiva problematizar a imagem e a pesquisa com o cotidiano escolar como potências para a emergência da fabulação criadora no movimento do pensamento produzido em redes de conversações, tecendo imagens outras e problematizando as imagens clichê. Discute o conceito de imagem, tomando como intercessores teóricos Bergson (2006) e Deleuze (1990). Usa como metodologia as redes de conversações com estudantes e professores de séries iniciais do ensino fundamental em uma escola pública, com base em pinturas de Glenn Brady. Conclui que a pesquisa se configura como espaço de aproximações e trocas do coletivo. Assim, a potência do falso e/ou do estranhamento não advém de um personagem dentro de uma imagem, mas de trocas entre imagens, pois não se espera mais que os heróis ajam, mas que qualquer um movimente o pensamento em seus processos de fabular outros mundos possíveis em que os saberes não sejam dogmáticos, mas múltiplos e plurais.
\end{abstract}

Palavras-chave: Imagens. Fabulação. Cotidiano escolar.

\begin{abstract}
It aims to problematize the image and the research with the everyday school as potencies for the emergence of creative fabulation in the movement of thought produced in networks of conversations, weaving other images and problematizing the cliché images. It discusses the concept of image, taking as theoretical intercessors Bergson (2006) and Deleuze (1990). It uses as methodology the networks of conversations, with students and teachers of the initial grades of a public elementary school, from paintings by Glenn Brady. It concludes that the research places itself as a space of approximations and exchanges of the collective. Thus, the potency of false and/or estrangement does not come from a character within an image, but from exchanges between images, because it is not expected more that the heroes act, but that anyone moves the thought in their processes of fable other possible worlds in which the knowledge is not dogmatic, but multiple and plural.
\end{abstract}

Keywords: Images. Fabulation. Everyday school.

Resumen: Objetivo problematizar la imagen y la investigación con el cotidiano escolar como potencias para la emergencia de la fabulación creadora en el movimiento de pensamiento producido en redes de conversaciones, tejiendo otras imágenes y problematizando las imágenes cliché. Discute el concepto de imagen, tomando como intercesores teóricos Bergson (2006) y Deleuze (1990). Utiliza como metodología las redes de conversaciones, con estudiantes y maestros de series iniciales de la enseñanza fundamental, en una escuela pública, a partir de pinturas de Glenn Brady. Concluye que la investigación se sitúa como un espacio de aproximaciones e intercambios del colectivo. Así, el poder de false y/o alejamiento no viene de un personaje dentro de una imagen, sino de intercambios entre imágenes, porque no se espera más que los héroes actúen, sino que cualquiera mueva el pensamiento en sus procesos de fábula otros mundos posibles en que el conocimiento no es dogmático, sino múltiple y plural.

Palabras clave: Imagen. Fabulación. Cotidiano escolar.

\footnotetext{
${ }^{1}$ Submetido em: 13 dez. 2018 - Aceito em: 12 fev. 2019 - Publicado em: 25 fev. 2019.

${ }^{2}$ Universidade Federal do Espírito Santo (UFES) - E-mail: anetemc@ @erra.com.br

${ }^{3}$ Universidade Federal do Espírito Santo (UFES) - E-mail: zanoniroseiro@ hotmail.com
} 


\section{Da potência das imagens}

Numa sala qualquer, começa-se uma conversa sobre pesquisa. "O que é uma imagem?" perguntou um pesquisador, deixando um grande vazio ressoar na turma. "Como assim, tio?" perguntou uma das crianças e, ao mesmo tempo, outra criança já desanda a falar: "Que tipo de imagem? Tipo uma foto ou uma arte? É isso que você quer dizer com imagem?”. Esse último, decerto, uma criança habituada às respostas corretas.

A turma, de certo modo, dá-se por satisfeita.

Mas o pesquisador não sossega. Aos poucos, vai evocando, sem nada mostrar, uma série de imagens clássicas: uma típica Cinderela com sua fada madrinha é convidada e substituída por uma versão dela, idosa apaixonada por um soldado; um filme é mencionado e discutido pela veracidade do que conta ou deixa de contar; uma propaganda política entra em cena e também uma série de memes sobre ela. "E aí, falamos de alguma imagem?"

As respostas são díspares.

Para Bergson (2006), o universo é constituído de imagens. Há tão somente imagens para todos os lados, imagens, imagens de imagens, imagens-percepção, imagens-afecção, imagens-movimento e por aí vai. As imagens, no sentido bergsoniano, são muito mais do que a lógica apontada, em primeiro momento, pelas crianças ou pelo que a arte clássica consegue enunciar por imagem. Em Bergson, as coisas são todas vivas em dada medida e, por isso mesmo, imagens, sendo o corpo apenas uma delas. O corpo para Bergson (2006) funciona como um centro de captação de outras imagens por meio dos sentidos, ou seja, imagens visuais, olfativas, gustativas, sonoras ou táteis, ligadas, entre si, por conexões estabelecidas por meio de fluxos de energias/vibrações em redes. A memória mora no corpo e, em certo sentido, é o próprio corpo, como morada das imagens, que é capaz de sentir o mundo.

As imagens são armazenadas, recebidas e alteradas por diferentes sistemas neurais que constituem dispositivos sensório-motores que, ao receberem as sensações, as memorizam, criam, em si, imagens das imagens. Esse armazenamento de imagens na memória permite que sejam realizadas algumas ações de forma automática que, com a repetição, produzirá um processo de fixação de uma imagem como imagem-lembrança que possibilitará, por sua vez, a realização de ações rotineiras, conduzindo, assim, a um tipo de imagem que Bergson denominará imagem-ação, solicitada quando uma situação semelhante ocorra - como o vestir-se pela manhã e dirigir-se ao trabalho.

Desse modo, as imagens que chegam do exterior, formarão uma das bases da memória: são as chamadas imagem-percepção (BERGSON, 2006). Justamente aqui Bergson se diferencia, em muito, da lógica tradicional do corpo e da imagem: se é possível conceber a imagem - e, com isso, também o corpo - carregando outras imagens, pensa-se, de imediato, em imagem dentro da imagem. Mas não apenas. Todo um corpo é imagem, todo um pensamento é imagem, a vida é imagem, e, por isso, não há dentro da imagem. As imagens fazem durar outras imagens sempre externamente. O que acontece, entretanto, é que essas imagens não conseguem absorver tudo que nos cercam e, portanto, operam selecionando alguns aspectos e excluindo outros. Possivelmente essas diferenças ocorram devido a certa 
intensidade, necessidade e motivação já instaladas em cada pessoa pela própria massa química energética que compõe o corpo/cérebro/sistema neural. Porém, algumas imagens passam por alterações de ordem subjetiva e, de certa forma, respondem por meio de imagensafecção, isto é, imagens que continuamente evidenciam as forças das outras imagens em movimentos infinitos.

Diante de uma imagem típica de um menino soltando pipa, veem-se, entretanto, forças infinitas habitando o corpo-pipa. "Eu acho que era uma pipa, né?" falou uma menina. "Mas parece que a pipa cansou de ser pipa e está tentando voar...". Imediatamente ela é interrompida por um menino-pipa: "Acho que a pipa já voou e o moleque tá tentando pegar, esse sem vergonha!" (E a turma entrou na gargalhada).

\section{Imagem 1. Boy with black bird kite}

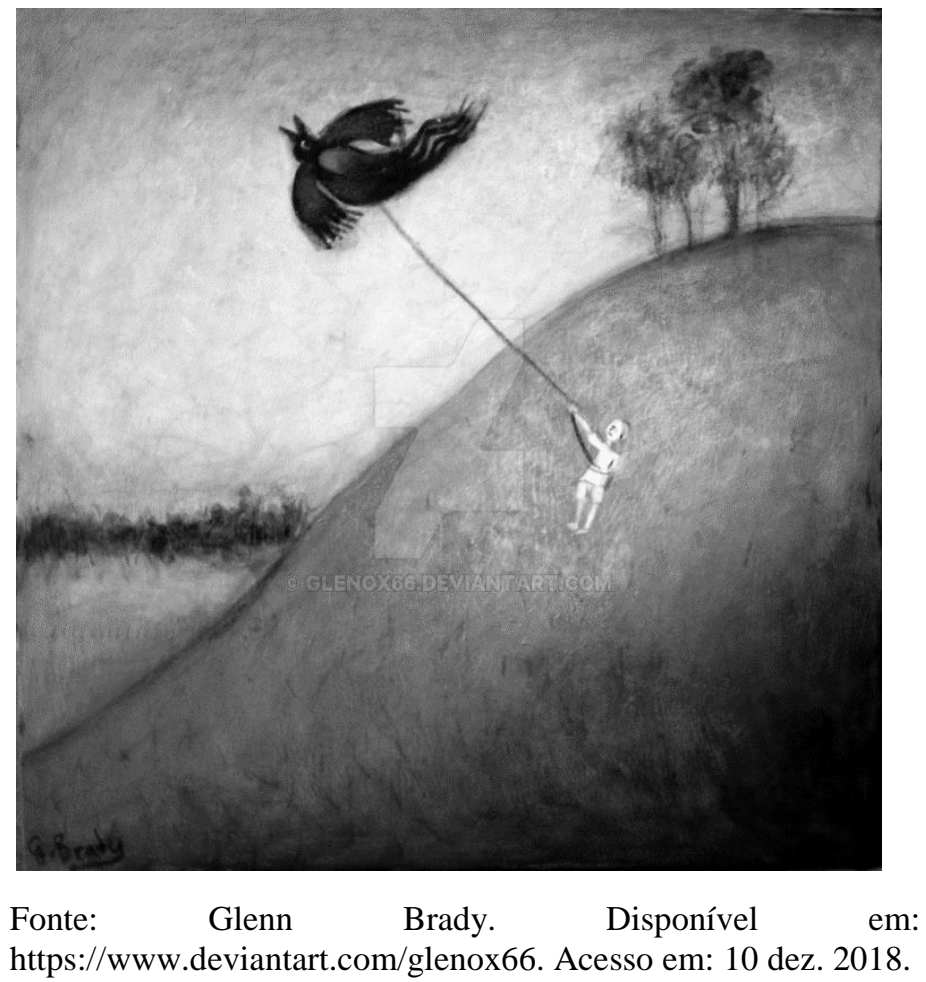

Pode-se, então, dizer que o pensamento, como morada e fábrica de imagens, é um fenômeno múltiplo no qual diversas forças atuam umas sobre as outras formando um "campo de energia". Sendo assim, a imagem antes de prisioneira pode ser um vento sem limites, nômade - sempre de passagem, viajante (REALI, 2017), sempre metamorfose infinita carregada doutras imagens. Portanto, mesmo datada e/ou referente a uma cultura, pode manter-se circulando indefinidamente, com sua capacidade de afetar e ser afetada, de modo que uma imagem, “[...] quando viaja pelo mundo, provoca a estranha sensação de que somos nós que viajamos" (REALI, 2017, p. 42).

No intuito de ampliar as redes de pesquisa a partir do uso de imagens e da fabulação criadora, esta escrita buscou, em Gilles Deleuze e Henri Bergson, os conceitos de imagem, pintura e fabulação, assim como a aposta teórica de que, por meio da imagem, é preciso 
mover-se em direção aos deslizamentos. Portanto, propusemo-nos a pensar a potência das imagens com um grupo de estudantes e professores do ensino fundamental no município de Cariacica-ES, tecendo redes de conversações (CARVALHO, 2009) com base em pinturas do australiano Glenn Brady.

\section{A inexistência de uma tela em branco e uma sala de aula}

Talvez a primeira pergunta que todo o professor se faça em sala de aula seja a pergunta deleuziana: como pintar uma tela sabendo que ela é nunca uma tela em branco? Como fazer com que as infinitas imagens preexistentes permitam-se ser rompidas, barradas, borradas e, ainda assim, entrar em jogo e aceitar brincar? Como lembrar que é preciso fazer uma imagem sobrepor-se a outras e todas se manterem em aberto, para que consigamos fazer ruir algumas lógicas imperativas, algumas vidas demasiadamente dogmatizadas?

O nomadismo da imagem como uma potência só é possível pela capacidade de nos fazer viajar por meio da memória fragmentada pelos tempos e espaços que nos impelem a viajar pelas culturas, espaços, tempos, história e imaginário.

Sendo assim, uma imagem pode desencadear um bloco de intensidades com potência para, conforme ressaltam Deleuze e Guattari (1997, p. 8), provocar o agenciamento do desejo "[...] deslocando-o no tempo, desterritorializando-o, fazendo proliferar suas conexões, fazendo-o passar para outras intensidades".

Samain (2002) escreve que somos condicionados tanto pela nossa forma de ver como pela peculiaridade com que as imagens olham para nós, pois imagens existem, vivem e fazem viver. Afirma que as imagens nos fazem pensar e nos movem em diversas direções. Reali (2017, p. 78-79, grifos do original) aponta três proposições: a) "Toda imagem nos oferece algo para pensar", possuindo, portanto, "força capaz de produzir movimentos de pensamento"; b) "Toda imagem é portadora de um pensamento, isto é, veicula pensamentos" para além da representação de objetos, veicula criações de quem a produz e de quem ao vê-la a recria. Ou seja, a imagem comporta tanto seu criador como sua recriação por quem a olha; c) A imagem é "uma forma que pensa", pois as imagens são formas que, entre si, se comunicam e dialogam independentemente de seus autores.

Desse modo, as imagens, constituídas de potências objetivas (de fora) podem passar por alterações profundas nas formas subjetivas (de dentro) conferindo singularidades que, compartilhadas, podem influir nos modos coletivos de ver e sentir o mundo. As imagens põem o pensamento para funcionar e podem fazê-lo estremecer... 
Imagem 2. The Hulk

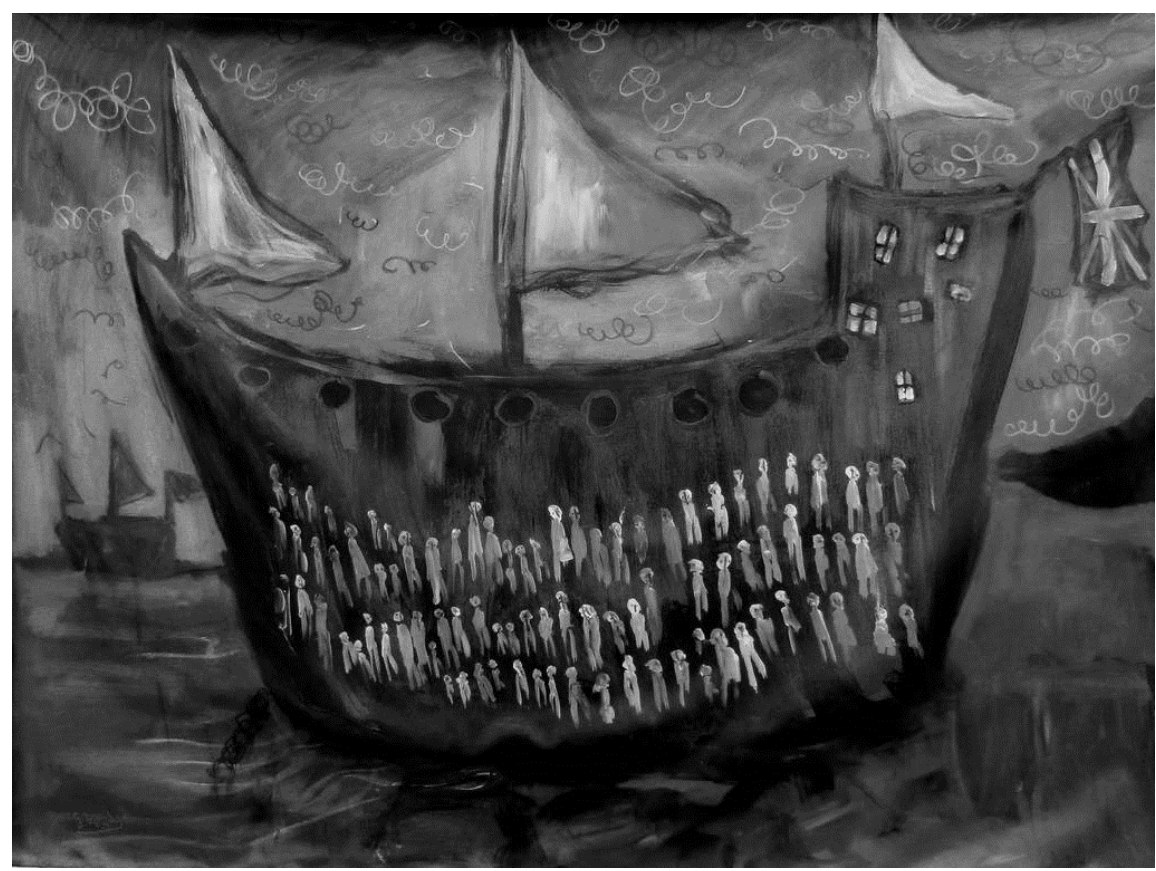

Fonte: Glenn Brady. Disponível em: https://www.deviantart.com/glenox66. Acesso em: $10 \mathrm{dez} .2018$.

A pintura The Hulk talvez expresse justamente o que ela seria, isto é, um navio-prisão, um modo de encarcerar corpos. Provavelmente percebamos isso pelas bandeiras e, conforme as crianças apontam, essas coisas fiquem evidentes pelas correntes que parecem sair do próprio navio, ainda que aparentemente nenhum dos corpos dentro do navio tenha corrente. "Mas ali tem corrente, ó! Ali, lá embaixo, entrando na água" falou uma criança. Outra, entendendo sua lógica, diz: "E é muito baixa para ser uma âncora. As âncoras partem de cima". Todavia, mesmo que, para uns, isso se evidencie, há ainda outras possibilidades, outros elementos que fazem da imagem outra imagem. "É mesmo um navio de escravos, tio?" perguntou um menino meio distraído. "Eu tava olhando o navio e lembrando de uma festa... olha só, tem crianças, tem velhos... e deve ser chato ficar dentro de um navio por muito tempo, né? Eu ia querer me divertir... será que não é isso não?”

$\mathrm{Na}$ verdade, o título da imagem, de prontidão, dá-nos essa resposta de imediato. Contudo, ali, por alguns segundos, a resposta correta perde seu sentido. Uma menina, dessas muito animadas e tagarelas, logo começou a festejar diante da imagem. "Uhul, feeeesta!" brincou ela, que, tão logo se cansa da brincadeira - ou é cansada pelo olhar severo do professor -, olhou novamente a pintura e inquiriu: "Mas, verdade o que o Weverton falou, tio, olha ali. Não tem muitos negros na pintura, eles eram mesmo prisioneiros?"

Há simplesmente coisas às quais não cabem respostas. Sim, o título The Hulk, lógica e linguisticamente, lança-nos à ideia de navios prisionais, com corpos colocados à deriva nos mares da Grã-Bretanha pelo simples fato de serem um risco à civilização. Todavia, a um só tempo, também é uma imagem carregada de outros valores. A intensidade do céu e da água faz da pintura uma peça agradável aos olhos, mas simultaneamente as cores dos corpos fazem 
com que nós, acostumados a corpos encarcerados negros, questionemos quanto esses corpos demasiado alvos possam efetivamente compor um sistema carcerário.

Cansado da discussão, um aluno finaliza: "Ao menos assim, a gente não tem que ficar olhando para a mesma coisa todos os dias, né? Meu pai falou que isso é uma das coisas que mais cansa... ver sempre a mesma coisa e não poder ver nada diferente. Acho que assim ia ser diferente, né? Num navio?"

No capítulo "A imagem do pensamento", da obra "Diferença e repetição", Deleuze (1988) enumera alguns postulados do que nomeia como imagem dogmática do pensamento, ou seja, daquilo que foi convencionado como o que significa pensar. Em síntese, essa imagem do pensamento sustentar-se-ia sobre pressupostos dados como naturais, de um suposto sujeito pensante que habitaria os ideais universalizantes do senso comum e do bom senso. Em outras palavras, nossas percepções são limitadas pelo sistema sensório-motor que ratifica as convicções ingênuas que sustentam o senso comum e nos iludem mediante a ideia de que compartilhamos um mesmo mundo passível de ser conhecido pelo saber humano e também modificado e dominado por nossa suposta capacidade de ação sobre ele (FARINA; FONSECA, 2015).

Na pintura, Deleuze (2007, p. 92) diz que isso é justamente o plano de imagens que antecipa qualquer tela em branco.

[...] uma série de coisas que se pode chamar de "clichês" já ocupa a tela, antes do começo [da pintura] [...], e se o pintor se contenta em transformar o clichê, deformá-lo ou maltratá-lo, triturá-lo em todos os sentidos, ainda assim trata-se de uma reação intelectual demais, abstrata demais, que deixa o clichê renascer das cinzas, que ainda deixa o pintor no elemento do clichê, ou só lhe dá o consolo da paródia.

Ou seja: todo o corpo é habitado por imagens demasiado habituais, demasiado dogmáticas, e, ao tentarmos fugir em demasia, acabamos por reiterar o império do clichê. A questão deleuziana, por isso, é paradoxal: como manter com o clichê um jogo no qual, ainda que evidente, o clichê deixe de governar?

Não damos a isso nenhuma resposta, mas exercícios. 
Imagem 3. Alone together

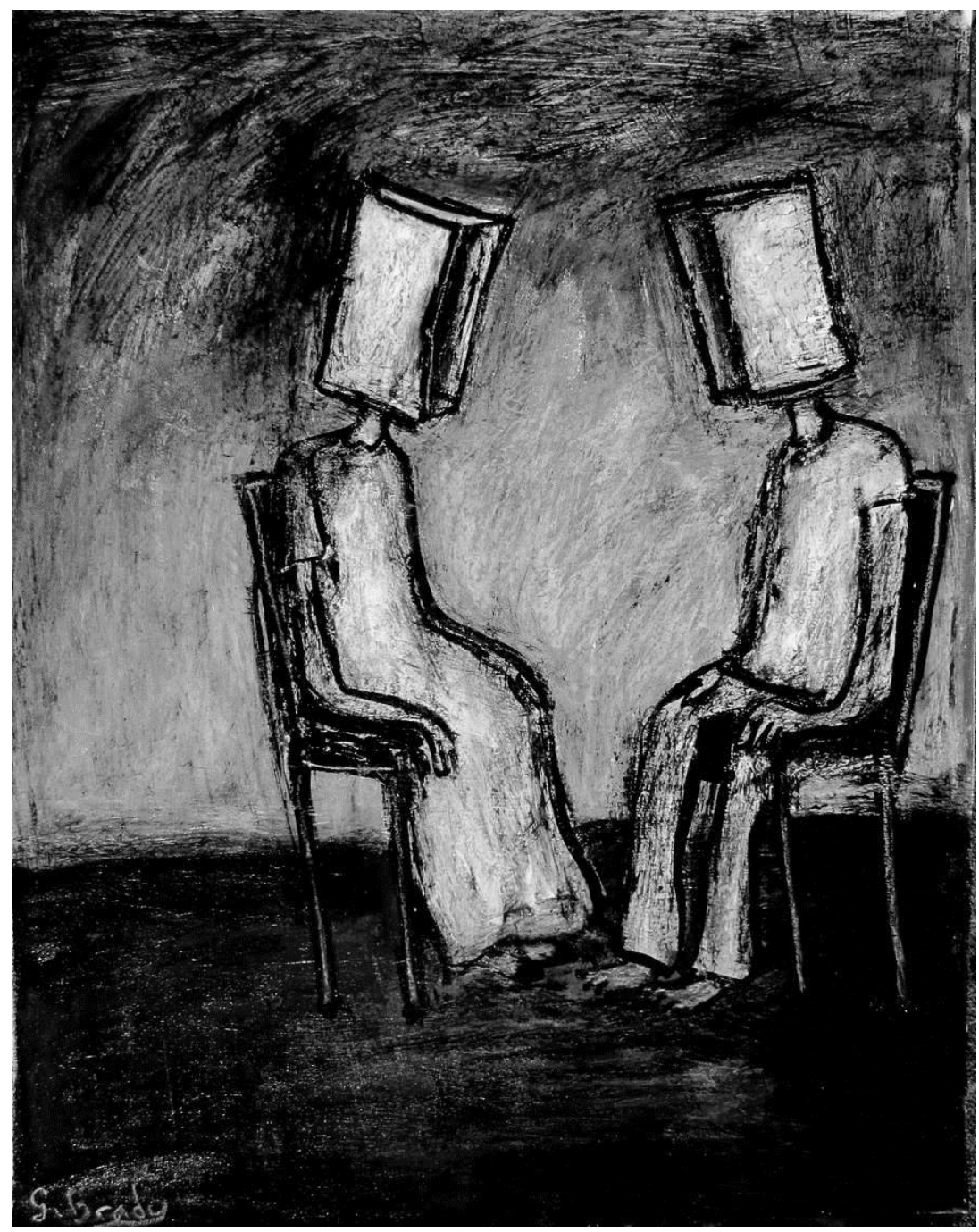

Fonte: Glenn Brady. Disponível em: https://www.deviantart.com/glenox66. Acesso em: 10 dez. 2018.

Criados na lógica do ver para pensar, a imagem Alone Together, do Glenn Brady, talvez nos coloque em uma leitura já confortável de que, no contemporâneo, nos isolamos diariamente diante dos corpos com quem convivemos. Poderíamos, em um primeiro contato, ver, acima da cabeça deles, velhas televisões de tubo ocupando o espaço dos corpos-cabeçacérebros. $\mathrm{E}$ isso, certamente, renderia boas conversas. Um aluno, diante desse primeiro contato-contágio, logo falou: "Eu sou um que faz isso. Eu já chego em casa louco para pegar meu celular e jogar... não paro até minha mãe gritar que tenho que almoçar e me ameaçar dar uma surra”. Muitos outros concordaram - força da imagem-clichê, do dogmatismo da individualidade enaltecida. Todavia, o mesmo menino que viu no navio uma festa, já foi logo falando: "Sei lá, será que eles não colocaram as caixas na cabeça para pensar? Porque pensar dói, né? É difícil pensar quando tem um monte de gente falando, quando tudo é muito colorido, quando a gente quer ver tudo, fazer tudo... aí só Jesus, menino! Tem que colocar caixa mesmo, tampar ouvido, fechar os olhos, não sentir os cheiros...”. 
Herdeira do dogmatismo cartesiano e aristotélico, essa lógica talvez jamais fizesse sentido. E deu para ver também que o professor da turma lutou muito para compreender e/ou dar corda ao pensamento insurgente. $\mathrm{Na}$ verdade, de início, o que rolou mesmo foi uma advertência, daquelas típicas de professor que quer corrigir o aluno.

O problema é que, de forma viral, a dificuldade do pensamento se espalha. E a imagem, depois disso, não parece ser outra coisa senão nossa dificuldade em pensar diante da falsa tela em branco que se alastra diante de nossos sentidos.

Relutante, o professor deixa-se afetar pela imagem reinventada pela criança. Minutos depois, ele faz questão: será que é possível encontrar, noutras imagens, a força do pensamento-difícil? Ou, como Deleuze falava, desse pensamento que nos violenta?

\section{Entre cinema, pintura e fabulação: os usos da imagem}

Gilles Deleuze foi, de muitos modos, um filósofo da imagem, seja por meio de suas leituras bergsonianas, seja por meio do teatro, da literatura, do cinema, da pintura, da filosofia ou de seus trabalhos com Félix Guattari. Deleuze empenhou-se largamente em fazer a imagem ser muito mais do que sua concepção clássica.

Em uma conversa curta com Hervé Guibert sobre a pintura e a escrita, Deleuze (2016, p. 190) diz não bastar fazer uso da imagem se a tudo o que couber nisso for sua descrição "ou se descreve o quadro e, então, um quadro real não é necessário", ou, quiçá, põe-se em virtualidade com a imagem, numa "efusão sentimental" que extrapola os limites da pintura pelos próprios elementos da pintura.

“A pintura inflama a escrita". Eis o título dessa conversa.

A nós, a questão não é apenas a pintura, mas justamente a própria condição da imagem artística levar os limites do real social a se trançarem sobre um plano - plano de composição, Deleuze e Guattari (2010) vão dizer - e esboçarem, nalgumas raras vezes, uma vida pujante, ainda que irreal, ainda que virtual.

Essa seria a força da imagem quando capaz de efetuar-se no real.

Deleuze (1990, p. 154) distingue no cinema dois regimes: um orgânico e um cristalino. Deleuze denomina "orgânica" a descrição que supõe a independência de seu objeto; e "cristalina", a descrição que substitui e cria o objeto e o apaga simultaneamente. Na descrição orgânica, o real é conhecido por sua continuidade, cujo regime utilizado é o das relações de causa e efeito. Já no regime cristalino, o real e o imaginário, o atual e o virtual são coalescentes.

Na narração orgânica os personagens reagem às situações, é uma "narração verídica, no sentido em que aspira o verdadeiro" (DELEUZE, 1990, p. 157), na qual o tempo depende da ação, do movimento. Na narração cristalina, as situações sensório-motoras dão lugar às situações óticas e sonoras puras em que os personagens não querem mais reagir, mas enxergar. O movimento decresce e as anomalias de movimento se tornam essenciais, em vez de serem acidentais. 


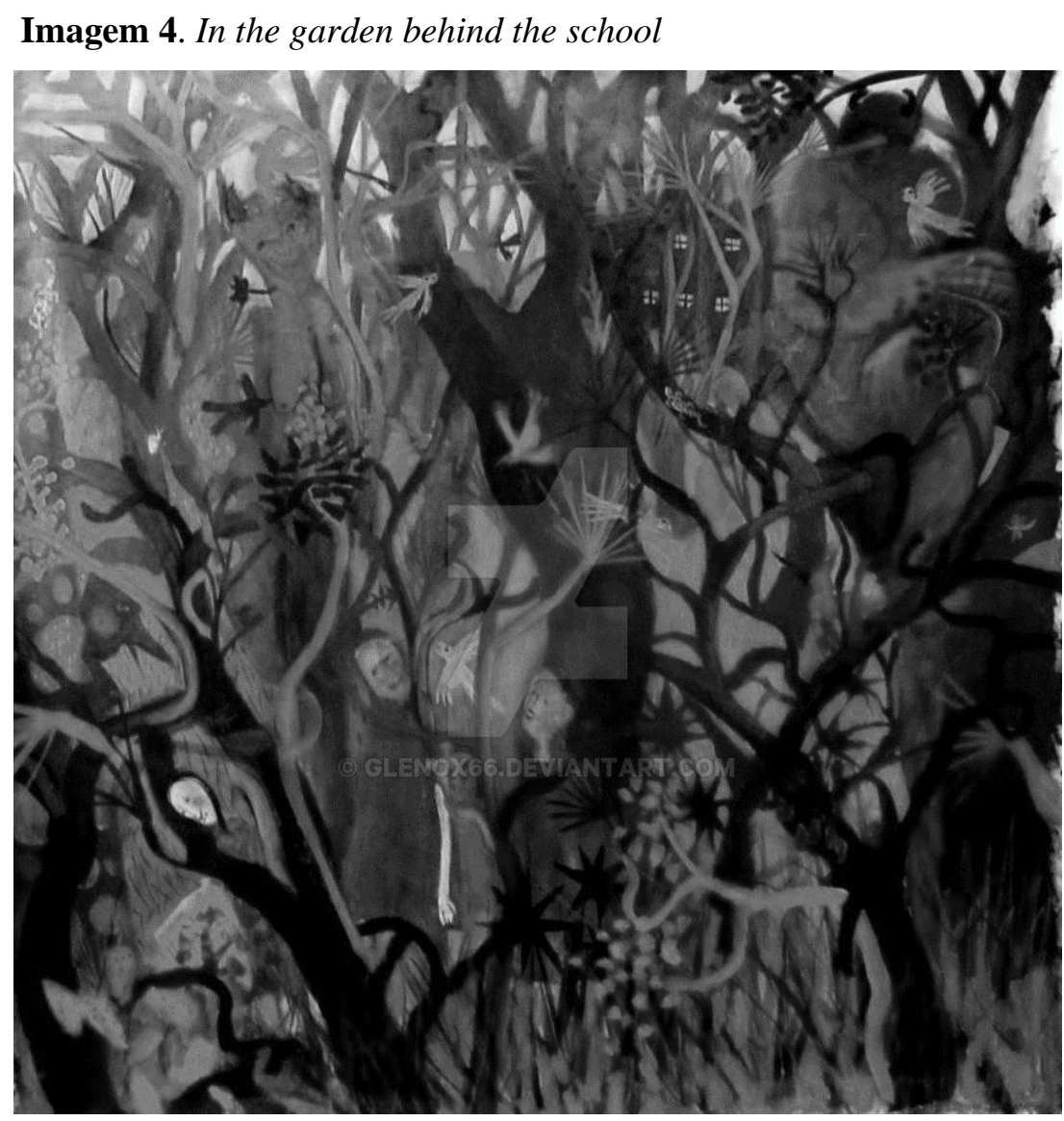

Fonte: Glenn Brady. Disponível em: https://www.deviantart.com/glenox66. Acesso em: $10 \mathrm{dez} .2018$.

"Nossa, tio, essa é a pintura mais bonita que você trouxe para a gente!" disse uma menina diante de In the garden behind the school. "Eu nem sei o que eu estou vendo, mas ela é muito bonita".

Às vezes, a imagem é capaz dessa estética que nada tem a ver com a sublimação kantiana, que nada tem a ver com o efeito quase anestésico da arte ofuscante, da arte clássica. "Eu também não sei o que eu tô olhando não, mas que me lembra alguma coisa lembra". "E que coisa é essa, João?” perguntou uma aluna. “Ah, sei lá, eu tenho que saber?”

Apesar dos risos, esse modo de se relacionar com a imagem lembra-nos precisamente da possibilidade da imagem no tempo, uma imagem virtual se relaciona com o atual como o passado com o presente. De acordo com Bergson (2006, p. 159): "É uma incontestável verdade a de que a lembrança se transforma à medida que se atualiza". Logo, a lembrança não perde a sua potência, visto que o passado coexiste com o presente, num processo de coalescência entre real e ficcional.

Esse processo ficcional e/ou de fabulação, que inclui a abertura para a problematização das imagens-tempos, revela o "[...] fundamento oculto do tempo, quer dizer, sua diferenciação em dois jorros, o dos presentes que passam e dos passados que se conservam. De uma só vez o tempo faz passar o presente e conserva em si o passado" 
(DELEUZE, 1990, p. 121), pois, por meio das imagens-tempo, a simultaneidade de um presente, passado e futuro torna o tempo não linear, complexo e inexplicável.

"Sabe que eu concordo com o João?" disse o pesquisador. "Essa imagem também me lembra algumas coisas que eu não tenho tanta certeza...". "Me lembra João e Maria, agora que estou conseguindo entender melhor o quadro...", disse uma garota. "Ali no meio parece que tem mesmo um menino, né? E parece que tá saindo um passarinho da boca dele, olha lá...", disse o "menino-resposta-correta". "Ou ele tá virando o passarinho, né? Eu ia querer virar para fugir daí...". "Ih, viaja não, João, onde já se viu alguém virar passarinho?". "Nossa, não era nada disso que eu ia falar", disse outro menino, "eu só tava pensando era em piqueesconde".

Memória e virtualidade compõem, nos corpos, um movimento impossível de ser previsto. Ali, onde a imagem de um jardim fazia um emaranhado na cabeça das crianças e levava, ainda, a uma calorosa discussão, uma menina tímida pegou uma folha em cima da mesa do professor e começou a fazer algumas notas sobre um jardim encantado, sobre árvores que falam e sobre corpos que, uma vez dentro do jardim, criam tudo de novo a ponto de adquirir a leveza de um pássaro.

$\mathrm{Na}$ imagem é que o tempo expressa toda a sua força. Mesmo porque a memória não está em nós, pois nos movemos numa memória-mundo (DELEUZE, 1990). Somos imagensvivas habitantes de uma imagem-infinita.

Ao falar sobre cinema, partindo da leitura de Bergson (2006) sobre o movimento, Deleuze $(1985 ; 1990)$, como vimos, distingue três tipos de imagens compondo a imagemmovimento: a imagem-percepção, a imagem-ação e a imagem-afecção. Para Bergson (2006), as afecções intercalam-se entre os estímulos que são recebidos (imagem-percepção) e os movimentos executados (imagem-ação), ocupando um "entre". Nos processos de aprenderensinar no cotidiano escolar, buscamos a potência desse "entre" como elemento produtor e produto de afecções que podem movimentar o pensamento e, desse modo, a aprendizagem inventiva (CARVALHO, 2014).

Porém, o cinema movimento - a imagem orgânica, a imagem-sensório-motora - se mantém conectado a um sistema de ação-reação, em que a narrativa consiste no desenvolvimento dos esquemas sensório-motores, segundo os quais os personagens reagem às situações em que se encontram ou atuam, de forma que tal situação fique visível ao espectador que seria levado, por sua vez, a uma identificação projetiva com esse personagem. Trata-se, assim, de um sistema composto por uma imagem-percepção (movimento de corpos como substantivos) e uma imagem-ação (movimento como verbo) centralizada num personagem, o que também sustentaria a relação sujeito conhecedor e objeto cognoscível da ciência tradicional, mantendo a posição do homem como agente de progresso do mundo (FARINA; FONSECA, 2015). Existindo apenas na reação, essa imagem propõe uma fraqueza que nos deixa à mercê dos estímulos externos. Já no cinema tempo, entre essas duas imagens se colocaria a imagem-afecção que, como dimensão afetiva, nos faria escolher uma percepção entre tantas outras possíveis que poderíamos arrancar do mundo. Ou seja, não poderia haver percepção sem afecção. Além disso, “[...] a afecção também produziria um 
intervalo entre a percepção e a ação, fazendo que a primeira demore, dure, se misture com a memória, produzindo pensamento" (BERGSON, 2006, p. 58).

Para cada imagem atual que retiramos do mundo surge, no intervalo afetivo, o seu duplo coalescente, indissociável e especular como uma imagem-virtual. O atual é sempre presente, mas, porque é presente, sempre muda, sempre passa, sendo substituído instantaneamente por outro presente. Assim, cada momento tem sua face atual como percepção e sua face virtual como lembrança. A memória passa a ser tomada, então, como um imenso reservatório virtual a ser atualizado conforme os encontros convocados por meio de cada novo presente. É aí que surge a imagem-tempo ou a imagem que dribla o clichê no próprio clichê; é aí, enfim, que surge a imagem do pensamento que Deleuze (1990) potencializa por meio da atmosfera cristalina e onírica em que as imagens nos mergulham. $\mathrm{O}$ plano de composição, afinal, conquista uma realidade material autônoma que faz os signos valerem por si mesmos, produzindo pontos de indiscernibilidade entre real e imaginário, sujeito e objeto, passado e presente, atual e virtual.

[...] todas as imagens reagem umas sobre as outras, sobre todas as suas faces e em todas as suas partes. É o regime da variação universal, que ultrapassa os limites humanos do esquema sensório-motor, rumo a um mundo não humano, onde movimento é igual a matéria, ou então rumo a um mundo sobre-humano, que atesta um espírito novo. É aí que a imagem-movimento atinge o sublime (DELEUZE, 1990, p. 54).

Esse tempo puro desconhece a hierarquia cronológica ou o julgamento da importância de cada acontecimento (DELEUZE, 1990). Somos incapazes de prever quando uma imagem virtual aparece dentro de outra ou quando uma imagem reúne, numa mesma imagem, acontecimentos de tempos cronológicos absolutamente distintos. Um momento qualquer dá a pensar a qualquer um: "é todo o real, a vida inteira que se tornou espetáculo" (DELEUZE, 1990, p. 105).

Assim, também, podemos encontrar o pensamento no cotidiano.

Em meio a esse movimento de pesquisa, discentes e docentes se articulam por meio das redes de conversações estabelecidas, fazendo circular os saberesfazeres ali produzidos, colocando-os em relação de força com os saberes pedagógicos instituídos. No entanto, essas conversações somente podem ser sustentadas pelas participações ativas e instigantes que articulam vozes, interagem a multiplicidade de assuntos num constante questionamento, em um espaço aberto com indagações, significações e problematizações sempre inacabadas. Assim, com base na afirmação do coletivo, sempre colocado como forças heterogêneas em relação ao movimento da pesquisa, começa a se articular um modo de fazer/pensar educação que busca constituir modos de atualizar o currículo, o exercício da docência, os processos aprendentes.

As trocas cotidianas na escola se fazem fundamentais à medida que é fortalecida a ideia de potência das ações coletivas, o individual vai-se misturando com o grupal, social, facilitando, assim, que as informações circulem e os saberes sejam ressignificados a todo o momento por meio de outros tantos saberes que compõem esse currículo praticado no 
cotidiano escolar. A pesquisa, portanto, nesse contexto se coloca como espaço de aproximações e trocas do coletivo.

$\mathrm{O}$ ato de pesquisar, pois, configura-se não como fronteira ou possibilidade, mas como espaço real de produção de experiências coletivas, como um acontecimento, espaço de vivências. A pesquisa, nesse contexto, vai constituindo-se à medida que os pesquisadores, professores e alunos se envolvem na vida no cotidiano escolar e para além dele, considerando sua complexidade, em modos de narrativas cristalinas, em modos de pesquisar não burocratizados, dogmatizados, normalizados, mas em modos de pesquisar como potência inventiva, que vai construindo, ao caminhar, uma pesquisa que é oportunizada por muitas tessituras e participações ativas dos sujeitos que compõem o universo escolar.

Nesta perspectiva, não é mais o esquema sensório-motor que é convocado, e sim a vidência, pois o acontecimento passa a ser uma situação ótica e sonora pura, investida pelos sentidos, uma descrição físico-geométrica/inorgânica que se faz por meio de uma imagem atual, mas que, em vez de se prolongar em movimento, se conjuga com imagens-virtuais formando um circuito independente do esquema sensório-motor.

É por isso que esse contínuo de variação universal é uma continuidade de duração numa profundidade de tempo, e não de espaço, só possível num pensamento livre do esquema sensório-motor, numa existência eminentemente trágica, só expressável por meio da arte, do delírio, da fabulação, do sonho... possível pela cintilação das imagens-cristal.

\section{Enfim, sobre a potência do falso nos processos de pesquisar inventivos}

As imagens-cristal talvez sejam as mais belas imagens-tempo. E, ainda que Deleuze tenha falado delas para o cinema, também a arte é capaz de cristalizar o tempo em imagens, de romper os liames de Chronos para fazer existir a duração. As imagens-cristal são as imagens da transparência e da leveza. Uma imagem que se instaura por uma espécie de duplo entre uma imagem atual e "sua" imagem virtual, seu espelho. Como os alunos veem, no contexto do olhar para a escola, para a cidade, para a vida, a possibilidade de superação da brutalidade instalada nos corpos embrutecidos por gestos de afeto e compaixão. 
Imagem 5. Girls in witches' hats

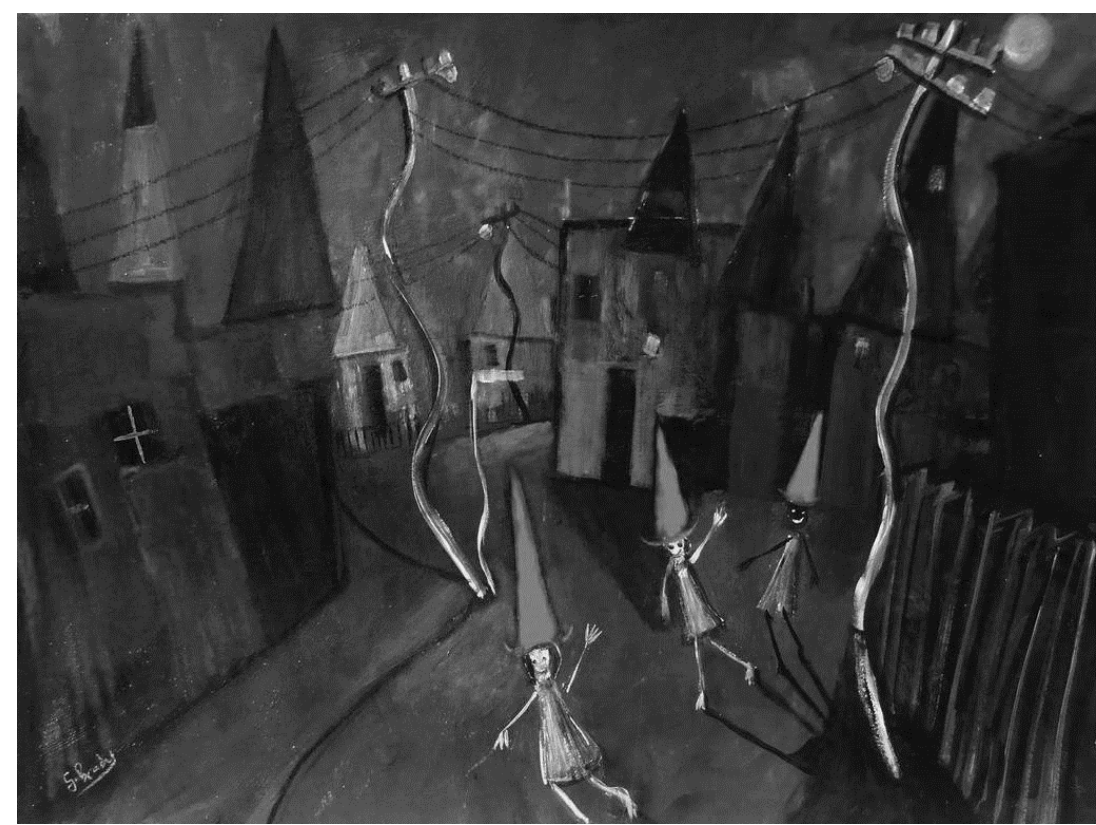

Fonte: Glenn Brady. Disponível em: https://www.deviantart.com/glenox66. Acesso em: $10 \mathrm{dez} .2018$.

Em dado momento, durante a conversa sobre arte, vida e obras de Glenn Brady, a coordenadora da escola aparece na sala de vídeo e conversa rapidamente com o professor. Então olhou para a projeção e falou sem pensar: "Caracas! Sabe o que eu mais gosto nessa pintura?" perguntou ela,

São meninas correndo na rua à noite sem medo. Cara! Sabe quanto tempo tem que eu não vejo isso? Essas nossas meninas de hoje não podem fazer isso... talvez aqui, que é bairro periférico e que todo mundo conhece todo mundo... mas onde eu moro? Posso nem sonhar em deixar minha filha brincar sozinha à noite... e as três aí? Sorrindo e brincando, nenhum adulto por perto.

Isso porque, como se ela, de repente, achasse estar atrapalhando a aula, pedia desculpas ao professor e saía de fininho, como se ela, de repente, fosse adulta demais para ver aquela pintura e, por isso, atrapalhava as meninas loucas a brincar pelas ruelas escuras de uma cidade.

É também um pouco disso: a arte, por vezes, mostra-nos os limites de nossas fragilidades.

Nesse sentido, buscamos, em nossas pesquisas, intensificar a fruição da experiência estética e a sensibilidade dos alunos, esperando expandir as problematizações e superar as aprendizagens somente recognitivas nos espaçostempos escolares.

Quando os professores e os estudantes problematizam por meio das imagens-tempo, das imagens-cristal, das imagens que rasuram o atual, eles o fazem de modo especular, ou seja, vendo a imagem atual/virtual dentro da imagem e vice-versa. O duplo da imagem que rasura o tempo não permite a existência da univocidade, não concorda com as "leituras" de imagens. Enquanto rasura, a imagem pode apenas ser sentida, por um contágio virulento e 
inquietante. Assim, apenas a imagem rasura o pensamento. Neste caso, a imagem é uma máquina de pensar, de pensar possibilidades de inverter o caminho habitual da vida, no caso, dos processos de aprender-ensinar praticados no cotidiano da escola, no intuito de renovar a existência e realizar, pelo pensamento problematizado, os tempos produzidos nas escolas, como o agenciamento do desejo de invenção dos processos de aprendizagem praticados no cotidiano escolar, produzindo tempos outros para o pesquisar (CARVALHO; ROSEIRO, 2015).

Desse modo, nos processos de pesquisar no cotidiano escolar, buscamos uma estética dos encontros nos quais os alunos e professores, por meio das imagens infinitas, possam pensar as escolas e a educação para além dos clichês, pois acreditamos, como Deleuze, que o interessante é ver e perceber o imperceptível, pensar o impensável e realizar o (im)possível.

As imagens-cristal não são o tempo, mas, por meio delas, pode-se ver o tempo não cronológico que encerra a poderosa vida não orgânica do mundo, em que os signos se tornam independentes dos objetos que os emanam. Há uma coexistência entre o atual e o virtual, entre o real social e a ficção. O visionário, o vidente é quem vê no cristal. E o que se vê no cristal é o jorrar do tempo como um desdobramento, uma explicação que desenvolve a limitação de um signo mundano na ilimitação de um signo de arte, pois a estrutura cristalina tem um sentido mais estético do que científico (DELEUZE, 2010).

Assim, a potência do falso e/ou do estranhamento não advém de um personagem dentro do filme ou dentro de uma imagem, mas é o próprio personagem conceitual criado na imagem, criando a imagem, em que a subjetividade só pode ser pensada em conexões com multiplicidades temporais complexas, pois não se espera mais que os heróis ajam, mas que qualquer um pense (no caso os alunos, os professores, os pesquisadores, no cotidiano escolar) que qualquer um movimente o pensamento em seus processos de pesquisar e fabular outros mundos possíveis nos quais os saberes não sejam dogmáticos, em que os currículos e a docência não sejam campos estáticos de única perspectiva, mas de imagens, fabulações, problematizações, saberes e acontecimentos múltiplos e plurais.

O falso como potência funciona como máquina de guerra nômade que instaura, no cotidiano escolar, o acontecimento pelo estranhamento e pela problematização, visto que sua potência almeja o fluxo de experimentos marcados pela vontade de transvalorização, paixão do novo e recuperação de forças por meio da criação (LINS, 2018).

No cotidiano escolar, os clichês precisam ser sacudidos, ser quebrados pelo movimento do pensamento que se faz potência - o real em contraponto à verdade fixada em imagem dogmática, buscando novos mundos possíveis e/ou novas possibilidades.

\section{Referências}

BERGSON, Henri. Matéria e memória: ensaio sobre a relação do corpo com o espírito. 3 ed. Tradução de Paulo Neves. São Paulo: Martins Fontes, 2006.

CARVALHO, Janete Magalhães. O cotidiano escolar como comunidade de afetos. 
Petrópolis/RJ: DP et Alii; Brasília/DF: CNPq, 2009.

CARVALHO, Janete Magalhães. Fabulando currículos entre imagens dos sonhos de Kurosawa. In: ANDRADE, Nívea; ALVES, Nilda (org.). Sonhos de escolas: conversas com Kurosawa. Rio de Janeiro; Petrópolis: FAPERJ/DP et Alii, 2014. p. 74-97.

CARVALHO, Janete Magalhães; ROSEIRO, Steferson Zanoni. Inventando tempos outros com Bergson e Deleuze em coletivos escolares: a potência da imagem-movimento e da imagem-tempo nas produções curriculares. Revista Sul-Americana de Filosofia e Educação - RESAFE, Brasília, n. 25, p. 83-96, nov. 2015.

DELEUZE, Gilles. A imagem-movimento. Tradução de Stella Senra. São Paulo: Brasiliense, 1985.

DELEUZE, Gilles. Diferença e repetição. Tradução de Luiz Orlandi e Roberto Machado. São Paulo: Graal, 1988.

DELEUZE, Gilles. A imagem-tempo. Tradução de Eloísa de Araújo Ribeiro. São Paulo: Brasiliense, 1990.

DELEUZE, Gilles. Francis Bacon: lógica da sensação. Tradução Roberto Machado. Rio de Janeiro: Zahar, 2007.

DELEUZE, Gilles. Proust e os signos. Tradução de Antonio Piquet e Roberto Machado. 2. ed. Rio de Janeiro: Forense Universitária, 2010.

DELEUZE, Gilles. Dois regimes de loucos: textos e entrevistas (1975-1995). Tradução Guilherme Ivo. São Paulo: Ed. 34, 2016.

DELEUZE, Gilles; GUATTARI, Félix. Devir-intenso, devir-imperceptível. Tradução de Suely Rolnik. In: DELEUZE, Gilles; GUATTARI, Félix. Mil platôs: capitalismo e esquizofrenia. Rio de Janeiro: Editora 34, 1997. p. 11-114.

DELEUZE, Gilles; GUATTARI, Félix. O que é filosofia? Tradução Bento Prado Jr. e Alberto Alonso Muñoz. 3. ed. São Paulo: Ed. 34, 2010.

FARINA, Juliane Tagliari; FONSECA, Tania Mara Galli. O cine-pensamento de Deleuze: contribuições a uma concepção estético-política da subjetividade. Psicologia USP, São Paulo, v. 26, n. 1, p. 118-124, 2015.

LINS, Daniel. Bob Dylan: a liberdade que canta. São Paulo: Edições Ricochete, 2018.

REALI, Noeli Gemelli. A desobediência do menor: rotas de fuga do cinema infantil. 2017. 237 f. Tese (Doutorado em Educação) - Programa de Pós-Graduação em Educação, Universidade Federal de Santa Catarina, Florianópolis, SC, 2017.

SAMAIN, Etienne (Org.). Como pensam as imagens. Campinas/SP: Editora da Unicamp, 2012.

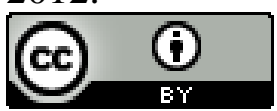

